\title{
Study on Various Techniques of Image Enhancement
}

\author{
Sandeep Kaur \\ M.Tech Scholar \\ Dept.of Electronics and Communication Engg. \\ B.C.E.T College Gurdaspur
}

\author{
Parveen Kumar \\ Assoc.Prof. \\ Dept.of Electronics and Comm.Engg. \\ B.C.E.T College Gurdaspur
}

\begin{abstract}
This paper has discuss the various techniques for image enhancement i.e histogram equalization, Brightness preserving bi-histogram equalization(BBHE), Dualistic SubImage Histogram Equalization (DSIHE), Minimum Mean Brightness Error Bi-HE Method (MMBEBHE), Recursive Mean -Separate HE Method (RMSHE), Mean brightness preserving histogram equalization(MBPHE).As well as it represents the comparison between the various techniques that shows the image enhances the overall contrast and visibility of local details. The review has shown that contrast enhancement approach based on dominant brightness level analysis and adaptive intensity transformation for remote sensing images.
\end{abstract}

\section{General Terms}

Enhance the contrast of images,comparison of different techniques of image enhancement.

\section{Keywords}

Image enhancement, different techniques of image enhancement HE, BBHE, DSIHE, MMBEBHE, RMSHE, MBPHE and Comparison table

\section{INTRODUCTION}

Image enhancement shows a really necessary part in different types of image processing applications. Image enhancement contains number of procedures are used to improve the visible act of an imag[1]e. The main intent behind image improvement is to improve features of an image[2]. An electronic digital enhancement technique gives several sets for improving an images. Mostly Image enhancement involves power and distinction adjustment, noise decrease, edges refining etc[5]. Contrast enhancement is specialized in the specific position of increasing the contrast in a visual to create different features rapider professed. There are different software places for improving the visible feature of low contrast images.

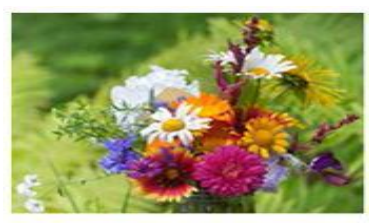

Input image

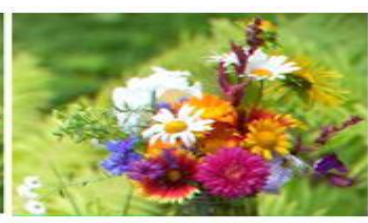

Output image

\section{DIFFERENT TECHNIQUES OF IMAGE ENHANCEMENT}

\subsection{Histogram Equalization}

It gives unlikely effects in images; nevertheless it is very helpful for images[1].Histogram Equalization (HE) is process which is put on improve the contrast of an image. In that it's possibly not required that the contrast of a graphic will be improved [2]. Often the histogram equalization shows that it can be inferior in comparison to contrast of a graphic is decreased. Before managing histogram equalization, it is necessary to understand the two methods which can be called as probability bulk function and cumulative distributive function. For all pixels in a graphic firstly evaluation PMF and $\mathrm{CDF}$.

\subsection{Brightness Preserving bi-histogram Equalization (BBHE)}

This process splits the image into two sections. [2].Then these two histograms are autonomously stable. To intend illumination of the resulting image leasing among the original mean and the mid gray level[4]. The histogram vary from 0 to M-1. This parting generates two histograms. The initial histogram has the set of values of 0 though the other has the value of $\mathrm{M}-1$.

\subsection{Dualistic Sub-Image Histogram Equalization (DSIHE)}

This process usages exactly the equivalent straightforward notion of BBHE mode. It disintegrated the image and then to be equal to the histograms of the sub-images independently [6].

\subsection{Minimum Mean Brightness Error Bi- HE Method (MMBEBHE)}

This technique also firstly decompose the image and after that put on the HE process to equalize the resultant sub-histograms in an independent manner[4]. In this technique the original image is decomposed I into two sub-images I [0, It] and I [ $1 \mathrm{t}$ $+1, \mathrm{~L}-1]$. The lowest illumination distinction between the original and the resultant image is attained.

\subsection{Recursive Mean-Separate HE Method (RMSHE)}

Recursive Mean -Separate HE is a prolonged variation of the BBHE technique[4]. In RMSHE as opposed to disintegrating the image only one time.it conduct image disintegration in recursive way to help protect the initial illumination around range $i$. HE is equal to RMSHE stage $0(i=0)$. BBHE is equal to RMSHE with $i=1$. The illumination of the result $\mathrm{I}$ mage is enhanced maintained by way of $r$ rises.

\subsection{Mean Brightness Preserving Histogram Equalization (MBPHE)}

This technique could be split in to two major terms called bisection-MBPHE and multi-sections MBPHE. Bisection process can preserve the illumination merely to a definite range. Multi-sections has features a greater mean brightness preservation as in contrast to the bisections MBPHE[4]. Multi-sections split the original image into s sub-histograms. Then all sub-histogram are then equalized independently.

\section{LITERATURE SURVEY}

Kanwal et.all(2010)[1] has shown a contrast enhancement technique for X-Ray image. A cross approach for 
improvement has been proposed Comparative evaluation of predicted method beside contrast improvement practices has been performed and results of predicted method are much better than different techniques. Ehsani et.all(2011)[2] planned a versatile and iterative histogram corresponding algorithm for contrast improvement .Furthermore, the outcomes obtaining the extreme truly real effect. The technology phases can probably vary considerably in regards to the image features and histogram. Ke et.all(2011)[3] planned a novel image improvement point that cartels bilateral tone change and saliency-weighted variance development procedures. Dissimilar several curve-based global comparison development practices, bilateral increases the mid-tone elements that usually contain critical shows, beside with the bright and dark sections. Jha, et al. (2012)[4] planned a contrast improvement strategy using scaling of internal noise. The system of improvement is attributable to noise-induced evolution of discrete cosine transform figures from an corrupt form to an improved form. This alteration is impacted by the internal noise existing because of inadequate brightness and might be taking an overall bi-stable process presenting dynamic stochastic resonance. The planned scheme used a regional versatile handling and enhances the image and color data though establishing good value. Jha Kumar et al.(2012) [5] planned a nonlinear resonance-based method for improvement of obscure and squat intensity images. A squat intensity is preserved as a sub-inception sign and noiseimproved show processing is placed on enhance their contrast. supplementary frequently to a visual and is consecutively threshold used prudently by complete averaging. Cheng,et.all (2012) [6] planned a method for the detection of overenhancement .The details for production over-enhancement are studied and surveyed extremely. An impartial principle for distinguishing over-enhancement is planned. Lee et al.(2013) [7] shown a contrast improvement strategy predicated on DBLA and adaptive intensity transformation for remote sensing imagesFirstly, apply DWT on the original images and then decompose the LL sub set in to three different levels by the log-average luminance Intensity transfer functions. The resultant improved image is received applying the inverse DWT. Chouhan et al.(2013) [8] planned a dynamic Stochastic resonance founded approach in spatial domain for the improvement of obscure- and squat-contrast image. The efficiency of somewhat might be better. DSR is used in a iterative style by relating the bi-stable planing with the depth standards of a low-contrast image. Kil, et. all(2013)[9] offered a to remove a haze process based on obscure channel preceding and brightness improvement methods. The traditional obscure channel preceding process eliminates darken and therefore reinstates shades of substances in the section, but it typically not study about the improvement of contrast. Other hand, the procedure enhance the local contrast of images. Reshma lakshmi et.all(2013)[10] has suggested a novel contrast improvement algorithm. Disadvantages of surviving contrast improvement procedures are amended by a scientific software called 'Fuzzy set'. Fuzzy set models might be formed to control the improbability related to images. Chen et.all(2013)[11] has planned a novel contrast improvement technique. It is based on histogram equalization and a unsharp masking. This planned algorithm usages HEBM to acquire contrast improvement. Maragatham et.all(2013)[12] planned an algorithm to design images presenting their contrast evaluate, to sort and differentiate involving to the unlike contrast.The original image is labeled possibly as low contrast or high contrast.If the labeled image is low contrast will be improved using the Stochastic resonance principle. The effects exposed that the planned mechanized process enhance the lower contrast image enhanced. Celik et.all(2014)[13] has presented an algorithm to enhance the contrast by spatial data of pixels. This process presents a new process to figure the spatial entropy of pixels. For every single grey level, the consistent spatial scattering is figured using a histogram of spatial positions of utmost pixels with exactly the same grey level. Cao gand et.all[1(2013)[14] has offered a multi-scale image improvement algorithm. The parametric comparison examine includes not only the illumination covering value, furthermore the comparison covering value of the human visual classification. The method of the comparison examine may be utilized aimed at each multiresolution disintegration system.

\section{COMPARISON OF DIFFERENT TECHNIQUES OF IMAGE ENHANCEMENT}

Table 1. Comparison of Techniques

\begin{tabular}{|c|c|c|c|c|}
\hline Ref.no. & $\begin{array}{l}\text { Name } \\
\text { of auth } \\
\text { or and } \\
\text { year } \\
\text { publicat } \\
\text { ion }\end{array}$ & Issues & Techniques & Features \\
\hline 1. & $\begin{array}{l}\text { Kawal, } \\
2011\end{array}$ & $\begin{array}{l}\text { Adaptive } \\
\text { histogram } \\
\text { has been } \\
\text { ignored }\end{array}$ & $\begin{array}{l}\text { Region based } \\
\text { co-ntrast } \\
\text { enhancem-ent }\end{array}$ & $\begin{array}{l}\text { Enhance } \\
\text { low } \\
\text { contrast } \\
\text { image }\end{array}$ \\
\hline 2. & $\begin{array}{l}\text { Ehsani, } \\
2011\end{array}$ & $\begin{array}{l}\text { Introduce } \\
\text { color } \\
\text { artifacts }\end{array}$ & $\begin{array}{l}\text { Adaptive and } \\
\text { iterative histo- } \\
\text { gram matchi- } \\
\text { ng algorithm }\end{array}$ & $\begin{array}{l}\text { Best result } \\
\text { in CIR }\end{array}$ \\
\hline 3. & $\mathrm{Ke}, 2011$ & $\begin{array}{l}\text { Adaptive } \\
\text { histogram } \\
\text { has been } \\
\text { ignored }\end{array}$ & $\begin{array}{l}\text { Bilateral tone } \\
\text { adjustment } \\
\text { and saliency } \\
\text { weigh- ted } \\
\text { contrast } \\
\text { enhancement }\end{array}$ & $\begin{array}{l}\text { Achieve } \\
\text { high } \\
\text { contrast } \\
\text { with little } \\
\text { noise }\end{array}$ \\
\hline 4. & Jha,2011 & $\begin{array}{l}\text { Decrease } \\
\text { the intensity }\end{array}$ & $\begin{array}{l}\text { Internal noise } \\
\text { induced enha- } \\
\text { ncement }\end{array}$ & $\begin{array}{l}\text { Enhance } \\
\text { visual } \\
\text { qualitys }\end{array}$ \\
\hline 5. & Jha,2012 & $\begin{array}{l}\text { Introduce } \\
\text { dolor } \\
\text { artifacts }\end{array}$ & $\begin{array}{l}\text { Dynamic stoc- } \\
\text { hastic resona- } \\
\text { nce based } \\
\text { technique }\end{array}$ & $\begin{array}{l}\text { Good per- } \\
\text { ceptual } \\
\text { quality }\end{array}$ \\
\hline 6. & $\begin{array}{l}\text { Cheng, } \\
2012\end{array}$ & $\begin{array}{l}\text { Decrease } \\
\text { the intensity }\end{array}$ & $\begin{array}{l}\text { Detection of } \\
\text { over enhance- } \\
\text { ement }\end{array}$ & $\begin{array}{l}\text { Decrease } \\
\text { the } \\
\text { intensity }\end{array}$ \\
\hline 7. & $\begin{array}{l}\text { Lee, } \\
2013\end{array}$ & $\begin{array}{l}\text { Introduce } \\
\text { Color } \\
\text { artifacts }\end{array}$ & $\begin{array}{l}\text { Dominant } \\
\text { bright-ness } \\
\text { level analysis } \\
\text { and } \\
\text { transforma- } \\
\text { tion }\end{array}$ & $\begin{array}{l}\text { Enhance } \\
\text { low } \\
\text { contrast } \\
\text { images }\end{array}$ \\
\hline 8. & $\begin{array}{l}\text { Chauhan } \\
\text {,2013 }\end{array}$ & $\begin{array}{l}\text { Decrease } \\
\text { the intensity }\end{array}$ & $\begin{array}{l}\text { Dynamic stoc- } \\
\text { hastic } \\
\text { resonance ba- } \\
\text { sed based tech } \\
\text {-nique }\end{array}$ & $\begin{array}{l}\text { Best } \\
\text { performa- } \\
\text { ce in color } \\
\text { and cont- } \\
\text { rast enha- }\end{array}$ \\
\hline
\end{tabular}




\begin{tabular}{|c|c|c|c|c|}
\hline & & & & ncement \\
\hline 9. & $\begin{array}{l}\text { Kill, } \\
2013\end{array}$ & $\begin{array}{l}\text { Adaptive } \\
\text { histogram } \\
\text { technique } \\
\text { has been } \\
\text { ignored }\end{array}$ & $\begin{array}{l}\text { Dehazing } \\
\text { algorithm }\end{array}$ & $\begin{array}{l}\text { Enhance } \\
\text { contrast } \\
\text { with a les } \\
\text {-ser color } \\
\text { distortion }\end{array}$ \\
\hline 10. & $\begin{array}{l}\text { Reshma } \\
\text { Lakshmi } \\
\text {,2013 }\end{array}$ & $\begin{array}{l}\text { Introduce } \\
\text { color } \\
\text { artifacts }\end{array}$ & $\begin{array}{l}\text { Fuzzy } \\
\text { technique }\end{array}$ & $\begin{array}{l}\text { Enhance } \\
\text { low } \\
\text { contrast } \\
\text { images }\end{array}$ \\
\hline 11. & $\begin{array}{l}\text { Chen, } \\
2013\end{array}$ & $\begin{array}{l}\text { Ignore the } \\
\text { use of ada - } \\
\text { ptive } \\
\text { histogram } \\
\text { equalization }\end{array}$ & $\begin{array}{l}\text { Compositive } \\
\text { contrast } \\
\text { enhancement }\end{array}$ & $\begin{array}{l}\text { Enhance } \\
\text { local and } \\
\text { global } \\
\text { contrast }\end{array}$ \\
\hline 12. & $\begin{array}{l}\text { Maragat } \\
\text { ham, } \\
\text { G.,2013 }\end{array}$ & $\begin{array}{l}\text { Usage of } \\
\text { adaptive } \\
\text { histogram } \\
\text { equalization } \\
\text { has been } \\
\text { ignored }\end{array}$ & $\begin{array}{l}\text { Algorithm to } \\
\text { model images } \\
\text { using local } \\
\text { contrast } \\
\text { portion }\end{array}$ & $\begin{array}{l}\text { Enhance } \\
\text { low } \\
\text { contrast } \\
\text { image }\end{array}$ \\
\hline 13 & $\begin{array}{l}\text { Celik,20 } \\
14\end{array}$ & $\begin{array}{l}\text { Spatial } \\
\text { entropy } \\
\text { based } \\
\text { enhance- } \\
\text { ment }\end{array}$ & $\begin{array}{l}\text { Enhance the } \\
\text { image of low } \\
\text { contrast }\end{array}$ & $\begin{array}{l}\text { Proves the } \\
\text { effectiven } \\
\text { ess }\end{array}$ \\
\hline 14. & $\begin{array}{l}\text { Cao } \\
\text { gand,201 } \\
4\end{array}$ & $\begin{array}{l}\text { Decrease } \\
\text { the intensity }\end{array}$ & $\begin{array}{l}\text { Multi-scale } \\
\text { image } \\
\text { enhancement } \\
\text { algorithm }\end{array}$ & $\begin{array}{l}\text { Preserve } \\
\text { local and } \\
\text { global } \\
\text { enhancem } \\
\text { ent }\end{array}$ \\
\hline
\end{tabular}

\section{CONCLUSION}

This paper shows a review on the image enhancement techniques for refining images has been done. Furthermore a evaluation has been formed that express the different methods, features and their confines. As of the review, that the DBLA has neglected the use of guided image filter to reduce the problem of noise which will be presented in the image. Thus, in near future, we will propose the Illuminate normalization for removing the uneven brightness of the images as well as 'Guided based image filter to preserve edges of enhanced images.

\section{REFERENCES}

[1] Manpreet Kaur, Jasdeep Kaur, Jappreet Kaur, Survey of Contrast Enhancement Techniques based on Histogram Equalization, 2011, Vol. 2 No. 7,pp 136

[2] Yeong-Taeg Kim , "Contrast Enhancement using Brightness Preserving Bi- Histogram equalization”, IEEE trans. on consumer Electronics, Vol. 43, 1998.

[3] Y. Wang, Q. Chen, and B. Zhang, "Image enhancement based on equal area dualistic sub-image histogram equalization method," IEEE Trans. on Consumer Electronics, vol. 45, no. 1, pp. 68-75, Feb. 1999.

[4] S.-D. Chen and A. Ramli, "Minimum mean brightness error Bi-Histogram equalization in contrast enhancement," IEEE Trans. on ConsumerElectronics, vol. 49, no. 4, pp. 1310-1319, Nov. 2003
2007.

[5] Kanwal, N., Girdhar, A. and Gupta, S., 2011, May. Region based adaptive contrast enhancement of medical x-ray images. In Bioinformatics and Biomedical Engineering,(iCBBE) 2011 5th International Conference on (pp. 1-5). IEEE.

[6] Ehsani, S.P., Mousavi, H.S. and Khalaj, B.H., 2011, November. Chromosome image contrast enhancement using adaptive, iterative histogram matching. In 2011 7th Iranian Conference on Machine Vision and Image Processing (pp. 1-5). IEEE.

[7] Ke, W.M., Chen, C.R. and Chiu, C.T., 2011 BiTA/SWCE: Image enhancement with bilateral tone adjustment and saliency weighted contrast enhancement IEEE Transactions on Circuits and Systems for Video Technology, 21(3), pp.360-364.

[8] Jha, R.K., Chouhan, R., Biswas, P.K. and Aizawa, K., 2012, September. Internal noise-induced contrast enhancement of dark images. In 2012 19th IEEE International Conference on Image Processing (pp. 973976). IEEE.

[9] Jha, R.K., Chouhan, R. and Biswas, P.K., 2012, February. Noise-induced contrast enhancement of dark images using non-dynamic stochastic resonance. In Communications (NCC), 2012 National Conference on (pp. 1-5). IEEE.

[10] Lee, E., Kim, S., Kang, W., Seo, D. and Paik, J., 2013. Contrast enhancement using dominant brightness level analysis and adaptive intensity transformation for remote sensing images. IEEE Geoscience and remote sensing letters, 10(1), pp.62-66.

[11] Chouhan, R., Jha, R.K. and Biswas, P.K., 2013. Enhancement of dark and low-contrast images using dynamic stochastic resonance. IET Image Processing, 7(2), pp.174-184.

[12] Kil, T.H., Lee, S.H. and Cho, N.I., 2013, May. A dehazing algorithm using dark channel prior and contrast enhancement. In 2013 IEEE International Conference on Acoustics, Speech and Signal Processing (pp. 24842487). IEEE.

[13] Pal, S.K. and King, R.A., 1980. Image enhancement using fuzzy set. Electronics letters, 16, pp.376-378

[14] Chen, X. and Lv, L., 2013, November. A Compositive Contrast Enhancement Algorithm of IR Image. In Information Technology and Applications (ITA), 2013 International Conference on (pp. 58-62). IEEE.

[15] Maragatham, G., and S. Md Mansoor Roomi. "An automatic contrast enhancement method based on stochastic resonance." In 2013 Fourth International Conference on Computing, Communications and Networking Technologies (ICCCNT), pp. 1-7. IEEE, 2013.

[16] Celik, T., 2014. Spatial entropy-based global and local image contrast enhancement. IEEE Transactions on Image Processing, 23(12), pp.5298-5308.

[17] Cao, G., Zhao, Y., Ni, R. and Li, X., 2014. Contrast enhancement-based forensics in digital images. IEEE transactions on information forensics and security, 9(3), pp.515-525. 